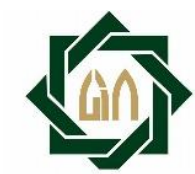

UIN SUNAN AMPEL

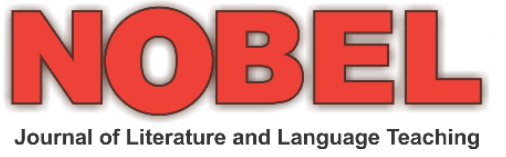

Volume 11, Number 1, April 2020, 38-54

available at http://jurnalfahum.uinsby.ac.id/index.php/nobel/article/view/269

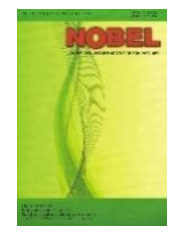

DOI: 10.15642/NOBEL.2020.11.1.38-54

\title{
DISCLOSING AUSTRALIAN NEWSPAPER'S IDEOLOGIES IN REPORTING POLITICAL NEWS THROUGH SOCIAL ACTOR REPRESENTATIONS STRATEGY: CDA PERSPECTIVE
}

\section{Ribut Surjowati $^{\bowtie}$}

Universitas Wijaya Kusuma Surabaya (UWKS), Jalan Dukuh Kupang XXV/54 Surabaya, Indonesia 60225

\begin{tabular}{l}
\hline Article Info \\
\hline Article History: \\
Received February 2020 \\
Accepted March 2020 \\
Published April 2020 \\
\hline Keywords: \\
CDA, ideologies, \\
newspaper, Social actors, \\
Papua, conflict \\
\hline
\end{tabular}

\begin{abstract}
This research aims at explaining how and why the Sydney Morning Herald communicates its ideologies in such a way through the social actors represented in news reports. Using Fairclough's and Van Dijk's model of CDA and Theo Van Leeuwen's framework of the representation of social actors, the study found that in terms of assimilation, nomination and categorization, functionalization and identification, and Impersonalization, the newspaper viewed the Indonesian government, army, and military officers as the Out group social actors, and Australian, Papuan activists and those who support Papuan conflict as the In group social actors. These categorizations serve different purposes. Those who are related to the Out groups express a purpose to emphasize their brutality, superiority, and dominance towards the indigenous Papuans. On the other hand, In groups social actors were indicated as peacemakers. These findings signaled Australia's political ideologies and hidden purposes towards Indonesia. Australia views itself as a liberal country which respects individual freedom; therefore, the government must protect and get justice, and, it is also Australia's responsibility to give aids to Papuans who are seeking better place as stated in the international law which gives a picture of how this country is concerned towards Indonesia.
\end{abstract}

(C) 2020 UIN Sunan Ampel Surabaya

\begin{tabular}{lr}
\hline${ }^{\circledR}$ Correspondence: & p-ISSN 2087-0698 \\
Email: $\underline{\text { surjowati88@gmail.com }}$ & e-ISSN 2549-2470
\end{tabular}




\section{INTRODUCTION}

Papua Conflict has and always become world interest and had become the highlights in international newspapers such as the Sydney Morning Herald (from now on SMH) since Papua is popular for its beauty and richness of natural resources. Many countries are interested in Papua conflict because this conflict potentially influences Papuans' demands to the Indonesian government to holding a referendum to let the Papuans choose between Independence or the remaining part of Indonesia. If this becomes a popular issue, many countries such as Australia and America will get significant benefits as they have observed that Papuans will choose the first choice. The Papua independence will make those countries easily control Papua.

As an influential newspaper in Australia, people rely on SMH in reporting issues in the rest of the world. They have no idea whether the news is reported objectively or not. The news is ideologically contested, as Fowler (1991, p.4) says that news is not a reflection of reality. Still, it is an illustration of reality construction. That is why the language of the news is always biased because the newspaper constructs some stories from its viewpoint, which is depending on the interest it has towards the news it writes (Fowler 1991, p.25). Furthermore, news producers have important roles in shaping society and setting the boundaries of what is talked about and how it is talked about because, without people's awareness, these groups of people can consciously influence people's conception of social and cultural phenomena (Rashidi \& Rasti, 2012). This shows that the language of powerful language producers has the power not only to recast the public impression of events, as when employing pleasant euphemism for ugly realities but also to make things happen.

$\mathrm{SMH}$, as one of the influential Australian newspapers in Australia, has an important role in shaping readers' valuation about every news it is reported, such as the way it reported the news about the conflict between Papuans and Indonesia Government. As an Australian newspaper published in Australia, read mostly by Australians and written by Australians. The mouthpiece of the Australian Government, SMH, is assumed to report the conflict in a different way. Thus, the style of the writing from this Australian newspaper is interesting to analyze because it is called into question about insisting ideologies the newspaper wants to present to the readers. It is assumed that this newspaper observes Papua conflict from its particular point of view as language is not value-free of fact (Fowler, 1996). The way to view a certain issue is always influenced by the hidden purposes and ideology that a media like SMH has. Using the powerful language, the journalists representing the proprietors' ideology can sometimes be successful in manipulating reality and affect people's perceptions about something. The production of the news is not the product of individuals, but institutionalized organizations (Van Dijk, 1988; Bell, 
1991; Fowler, 1991) and journalistic texts are the outcomes of specific professional practices and techniques which can be quite different with quite a different result (Richardson, 2007, p.77).

Many readers, particularly those who belong to the less fortunate level of society and education are usually do not realize that the news they are reading is far from reality. It is socially and culturally determined (Caldas-Coulthard, 2003, 2012); it is easy for them to be influenced to be aggressive and rebellious. Therefore, this research was conducted to make the readers critical by showing them that language in the newspaper is bias and ideology contested and that the language used by the newspaper representing hidden purposes. Some researches about newspaper ideology focusing on identifying how the ideology was communicated had been done. Still, just a few of them examined why such ideology formulations were communicated so that the readers could not determine the reasons behind those formulations (Rashidi \& Rasti, 2012; Liao, 2012; Naghty, 2010; Ghannam, 2011; Vo, 2011). The analysis only focused on describing the relationship between the interaction and social context but did not find out the background of construing such ideologies. Such researches just showed to the readers that some journalists used some strategies in communicating its ideologies. However, they could not explain to the people about reasons underlying the use of those strategies.

This current research had different perspectives from the previous ones. By combining Theo Van Leeuwen's (1996) theory about the representation of social actors and Critical Discourse Analysis (CDA), such ideological text can be examined because CDA is considered as a significant tool for investigating text as it is believed that the language used in the text is often used as the media to accomplish the change and maintenance in society (Bloor \& Bloor, 2007). Wodak and Meyer (2006) added that CDA is focused on the examination of bias and transparent structural relationship of dominance, discrimination, power, and control as represented in language, as Fairclough $(1989$, p. 2) Power is related closely to ideologies and ideologies are closely related to language because language is a medium of showing domination and social power. Therefore Language is ideologically contested.

This research is aimed at explaining how and why SMH communicates its ideologies in such a way through the social actors represented in the news reported.

\section{REVIEW OF LITERATURE}

This part is providing an overview of the literature that supports the data analysis. It is discussing Critical Discourse Analysis, which is a fundamental method for critical analysis, theory social actors' representations, and theory of Ideology. 


\section{Critical Discourse Analysis (CDA)}

CDA is a field of study concerned about studying and analyzing written and spoken texts to disclose the discursive sources of power, dominance, inequality, bias, and ideology (Van Dijk, 1998). It studies how these discursive sources are maintained and reproduced within a specific political, historical, and social context. It examines how those social power abuses are enacted, reproduced, and resisted in the form of text and talk in a political and social context. In other words, CDA concerned about how power, dominance, and inequality are represented in a text, either spoken or written.

Fairclough (1989: 24) mentions that "a text is a product rather than a process - a product of the process of text production." When the text is produced, it always includes the production and interpretation process, that is why to analyze a text, one must consider social condition where the text is produced and interpreted: the non-linguistics aspect of society since this aspect can influence the writer's or readers' in producing and interpreting the text. There are three dimensions in the analysis, namely; 1) Description of formal properties of the text (micro-level of analysis), which consists of lexical, grammatical, and textual structures; however, this research was focusing on lexical structures. It is also the stage of analysis in which the theory of social actors' representation was implemented. 2) interpretation of the processes of production and interpretation or interaction with the text by the producers and interpreters (Meso level of analysis). In doing the interpretation of SMH text, the researcher related the analysis to the social beliefs, values, attitudes, and opinions as Van Dijk (1998) say as a cognitive approach and explanation of the interaction and social context as well as their social effects (the macro level of analysis). In this stage, the analysis is done by viewing how the member resources (MR) are reproduced in the production of discourse, and they maintain or change the existing ideology in society. This stage will disclose the reasons behind text productions (Fairclough, 1989). 


\section{Van Leeuwen's Categorizations of Social Actors}

There are ten categories used by Van Leeuwen in viewing the social actors (1996: 28-47) namely 1) Exclusion: the social actors are either completely left out or de-emphasized, 2) Role Allocation: the social actors are represented through the roles they play, 3) Genericization and specification: the social actors are either represented as classes of people or as specific identifiable individuals, 4) Assimilation: the social actors are either represented as collectives or as individuals., 5) Association and dissociation: the social actors are viewed as collective groups which are associated with each other because of common interest, 6) Indetermination and differentiation: the social actors are viewed as unspecified "anonymous" individual or groups such as the use of someone to represent social actors, 7) Nomination and categorization: the nomination strategy is used when the social actors are identified in terms of unique identity, and categorization identifies social actors in terms of identities and functions they share with others, 8) Functionalization and Identification: the social actors are viewed based on the function they perform and the identification of what social actors are, such as relational identification, physical identification and classification, 9) Personalization and Impersonalization: the social actors are personalized as human or impersonalized through abstraction, 10) Overdetermination: the social actors are represented as participants in more than one social practices at the same time.

\section{Ideology}

In his framework of ideology, Van Dijk (2000, p.44) and Fiske and Taylor (1991) in Van Dijk (2012) formulate the four principles which enable people to view hidden ideology, which is expressed in numerous ideological statements. Those are emphasizing 'Us' or In group; friends, allies or supporters, positively, 'Them' or Out group; enemies or opponents, negatively, deemphasizing negative things about 'Us'; and deemphasize positive things about 'Them.' These four viewpoints play an important role in wider people's knowledge about "positive selfpresentation" and "negative other-presentation." Positive self-representation highlights individuals' positive behavior when emphasizing positive things about 'Us' and negative things about 'Them.' Meanwhile, the negative other-presentation describes that there would be negative things addressed to 'Us,' positive things addressed to 'Them' (van Dijk, 2000, 44). This indicates that the term 'them' always refers to negative beliefs in a social context, while the term 'us' refers to positive beliefs. 


\section{METHOD}

This research is a descriptive qualitative research which specifically categorized as discourse-analytical media research. The focus is on finding ideologies underlying in a newspaper discourse, SMH. The data were taken from 20 news reports about Papua conflict in $\mathrm{SMH}$. To search for the way SMH communicates its ideologies. Why such ideologies were communicated, some procedures were done by employing three steps in Fairclough's CDA, which are description, interpretation, and explanation. The procedures of data analysis are; 1) the data were classified into those belongs to Van Dijk's model which operate "In and Out" groups analytical categories, the Out group consists of the Indonesian Government, including the Indonesian military. In contrast, the In group consists of those who support Papua conflict including Australia, OPM, and the indigenous Papuans, 2) Van Leeuwen's framework of the representation of social actors was implemented to describe and interpret the social actors' representation in the newspaper from each group, in this stage, 3) the newspaper's ideologies could be uncovered after the social actors' representation was done, 4) the step of explanation was done to find out the reasons of SMH journalists having such ideologies were examined, 5) The findings were verified.

\section{RESULTS AND DISCUSSIONS}

\section{Description and Interpretation}

\section{Impersonalisation}

Impersonalisation is the strategy of impersonalized social actors. They are represented by other means such as abstract nouns or concrete nouns whose meanings do not include the semantic feature "human" (Van Leeuwen, 2008). Furthermore, He confirmed that different purposes were served in impersonalisation strategy; it can background the identity and/or role of social actors, it can lend impersonal authority or force to an activity or quality of a social actor, and it can add positive or negative connotations to a social actor's activities. This categorization was used by SMH to describe the Out and In group social actors with slightly different purposes. The similarity purpose is to build preconceptions about the identity of the social actors as they are identified as powerful and authorized actors.

(1)......and Indonesia has already flagged concern about the non-government organization (NGOs) advocating independence for Papua (SMH).

(2) Although Jakarta made an autonomy deal with the province almost 10 years ago, its indigenous Melanesian people remains the country's poorest while migrants flood into the resource-rich area and dominate business and paid employment, further marginalizing the Papuan. (SMH). 
The lexical, Indonesia, was used to represent Indonesian authority who suspected NGOs as a provocateur for Papua freedom. In contrast, lexical Jakarta referred to the Indonesian Government as the powerful authority which had decided to give autonomy to Papua. The strategy of using impersonalisation explicitly did not tell about the negative attitude of the actors. Still, implicitly it is a strategy to emphasize the role of those social actors as being dominant and powerful actors who set their rules to the Papuans with a barbarous act. A similar strategy was implemented when SMH convinced the readers that the Indonesian Government officers were seriously wanted to listen to Australia, that Indonesia considered Australia as an influential country to the conflict in Papua, as seen in:

(3) in Indonesia has recalled on the Prime Minister, John Howard, to hold direct talks with

its Presidents, SBY, to resolve the crisis $(\mathrm{SMH})$

The use of impersonalisation in this case shows that all the actions and plans done by Indonesia were not based on individual interest but its institutional matter, which was absolutely a serious conflict involving Australia.

The strategy of impersonalisation was also found in SMH when it reported the actors from the In group. This media used the terms Federal cabinet, Immigration Department, and the Australian Government to shape readers' opinion that the actions did by those social actors were not based on individual interest but institutional.

(4) in the light of the bitter diplomatic breach that followed Canberra's belated support..........., the Australian Government is trying to avoid a similar conflict in Papua $(\mathrm{SMH})$

(5) Federal cabinet is likely to consider other options and looking at offering funds to Jakarta to help its implementation of autonomy in Papua as a way of dampening independence calls (SMH)

The above data enlightened how the authority in Australia concerned about peace in Papua and Indonesia. This media tried to show to the readers that Australia, as a nation, did not have a hidden mission in Papua conflict. These In group social actors were identified from their goodwill to help Indonesia solve the problems. 


\section{Assimilation}

When the social actors are referred to as groups, the writer employs assimilation strategy, and two major kinds of assimilation are aggregation, which quantifies and treats the social actors as statistics and collectivization, which does not treat them that way (Van Leeuwen, 2008, p. 38). In this research, six data were found using assimilation strategies in which the social actors there were collectivized in a specific term such as Indonesian troops, and delegations, the army, the military and police, both military and presidential spokesmen. This categorization gives an idea that the social actors were homogenous and consensual group executing the Papuan separatist organization (OPM), as seen in the following example;

(6) Indonesian troops have been involved in a low-level conflict with Papuan separatist organization since the area was annexed by Indonesia in 1969 in a vote widely seen as a sham by international monitor. (SMH)

The term Indonesian troops was used to represent all the members of the Indonesian army; therefore, all the conflict involved all the members of the troops, and it is systematic. This strategy could shape the readers' opinion that the Indonesian army was officially instructed to execute the activists of OPM because of having provoked Papuans actively to be independent of Indonesia.

(7) The police were out of control and beating local journalists and suspecting protesters, but a relative calm soon returned to Jayapura $(\mathrm{SMH})$

The term police were described as an organization that consists of trained soldiers who have duties of protecting the civilians. However, the above datum showed negative attitudes of the police because of their brutality in confronting the chaos. This assimilation strategy done by SMH was to cover its lack of accurate information about the numbers of the actors involving in the riot, and it did not have accurate data which actors behind this brutal action, therefore, this media just mentioned the institution which was responsible for its uncontrolled action towards the unarmed journalists. This will be able to shape the readers' opinion that Indonesia was behind this riot.

When the Out group social actors were emphasized from their harsh collective actions, the different way was given to the In group social actors, which consisted of Papuans activists, the indigenous Papuans, and Australia. The journalist of SMH tended to show the suffering of Papuans and the goodwill of Australia to help and support them.

(8) Papuan activists insist that more than 38 died at the hands of Indonesians (SMH)

In datum number 8, Papuan activists were described as heroes for the indigenous Papuans for their strong movement to show to the world that Indonesia was the only cause of Papuans' suffering. Furthermore, the use of assimilation strategy (Papuan activists) was used to 
generalize the actors to cover media's poor data about the real actors but gave a positive impact to readers' alignments to the In group. Meanwhile, SMH once used nominal Two while it mentioned the victims of the tortures;

(9) Two Papuan victims are recorded on the video - one naked and being burned, while the other is clothed and has a large knife placed under his nose as he is being questioned by the men $(\mathrm{SMH})$.

By mentioning the number of Papuan activists, the journalist covered its bias in reporting the news as the victims were identified clearly. This media showed the readers that it had accurate and reliable information about the victims so that the readers would think that it is reliable information.

Another report which was presented by using assimilation strategy was found when SMH wrote about the difficulties and unsafety of western journalists in reporting about the conflict in Papua.

(10) Fairfax media has confirmed with the Indonesian Department of Foreign affairs that the "clearing house" process remains the only legal route to West Papua (SMH).

The In group social actor in the above is Fairfax media. It was not specifically mentioned whether it is SMH, the Australian, or the Herald. Therefore, this strategy was implemented to manipulate the readers' attention that Indonesia had a hidden agenda towards Papua and that the outsiders must have not interference with this. The term Fairfax media, which seemed to represent all the Fairfax, was used to assure the readers that there had been journalists' restriction in Papua.

\section{Nomination and Categorization}

SMH nominated the Out group social actor, Susilo Bambang Yudhoyono, by honoring him with his title "Dr" as having a role in the solution of the conflict, Dr. Yudhoyono was told to give promise to Papuans if the Papuans asylum seekers were willing to go home.

(11) Dr. Yudhoyono has floated a new type of "special autonomy" for West Papua, including the creation of an indigenous upper house of parliament in the province and more development assistance (SMH).

The above datum gives a meaning that, despite his political competence, the President of Indonesia, Susilo Bambang Yudhoyono, was viewed as a president with academic competence. The journalist wanted to focus the readers on the quality of the social actors and showed to them that special autonomy was assumed to work well to resolve the conflict in Papua since the proposal was assured by a competent President. The title $D r$. was included again when SMH mentioned Yudhoyono as this media relied on him for giving justice to the Papuans after the minister confessed that there were tortured done by the Indonesian military. The social actor is 
described as having a positive attitude as he demanded human rights and justice towards Papuans.

The positive evaluation was expressed not only by nomination but also by categorization, as found in the data below. This strategy serves a purpose to emphasize the important role of the social actors in the activities; in this case, SMH categorized Ali Hamdan Bogra as Colonel Ali Hamdan Bogra. The use of rank Colonel would be able to ensure the people that he had the capacity to tell the truth that there was an instruction to the soldiers not to take attack the village after the death of their comrade done by the separatists. This strategy was used to show the readers there was an instruction from the commander not to attack the village. In this case, there is a positive evaluation towards the Out group social actor, Colonel Ali Hamdan Bogra, because he was described as having the same quality as most of the In group social actors such as $\mathrm{Mr}$. Howard, Dr. Peter King who were peace seekers. However, it emphasizes the fact that there were some riots in the village between the Papuans and the military officers. The positive evaluation given to the Out group shows the opposite description following what Van Dijk mentioned that the Out group are the enemies or opponents who have different ideologies from the In group. They always refer to negative things; however, this positive evaluation carries implied messages SMH wanted to communicate with the readers.

There was a different view when the newspaper identified the In group social actors. They were categorized as well as nominated differently such as in mentioning Herman Waingai as a separatist, and Prof. Ron May, original specialist, as it can be seen in the following data:

(12) the Indonesian military was using the same tactics of terror in West Papua that were employed during its bloody reign in East Timor, and Australia should step in to mediate a peace settlement, warn separatist Herman Waingai (SMH).

SMH called Herman, a separatist, as he was one of the Indonesian military's target, to convince the readers that the information was valid. Different strategies in which was categorization and nomination were mixed in calling Ron May, who is labeled as a regional specialist at the Australian University in Canberra and nominated as Prof. regarding his statement about Indonesia government superiority not to sit down and dialogue with Papuans to settle the conflict.

\section{Functionalization and Identification}

Functionalization and classification serve a similar function, which is to generalize and emphasize the roles of the social actors. This categorization was both used to identify the Out group and In group social actors with the same purpose to highlight the position of the social 
actors as having the authority to talk the issue so that it highlights the truth and the stretches of actions had done; for example;

(13) The Indonesian intelligence chief, Major-General Syamsir Siregar, this week accused Australian non-government organization of political interference in most Papua (SMH).

SMH was intentionally applying this categorization to spotlight the social actor's important position regarding his accusation to Australia's goodwill. This categorization is ideologically contested since it includes the social actor who is The Indonesian intelligence chief. This issue was a serious matter and needed a serious response from Australia. It was an attempt of exaggerating Indonesia as a trouble maker country, as it is also seen in the example;

(14) A presidential spokesman, Andi Malarangeng, also suggested Mr. Howard should order the navy to prevent more boatloads (SMH).

Examining the classification categorization, the reader of SMH would be led to Australia's strong willingness to help Indonesia fixing the conflict in Papua. However, this good would elicit a bad response from Indonesia and worsen the relationship. In this case, Australia would be one of the nations which obey an international society, and it proved that Australia was a peacemaker country. The following example supported the activity;

(15) Tony Burke as the Labor's immigration spokesman, backed Mr. Howard's refusal to apologize to Indonesia for granting asylum to 43 Papuans (SMH).

This categorization is an important strategy of degrading the Indonesian Government as Van Leeuwen (2008) says that the category of "belonging to a company or organization" plays a more vital role in identification. The identification of the actors who are from Indonesian military officers and their positions in the institution prompt the readers to focus their attention to the actors as they will be identified easily as the officers from Indonesia not from other countries and also by generalizing the social actors, the readers will neglect the existence of the social actors. They will start focusing on the activities of the actors. Hence, as SMH called Peter King of Sydney University, it emphasizes the importance and quality of the social actors regarding the statement given.

\section{Specification and Genericization}

Specification is the strategy of representing the social actors as specific identifiable individuals (Van Leeuwen, 2008, p.41). In identifying the In group social actors, SMH characterized the social actors in collective and specific terms. Both of them serve different purposes but run to the same destination, which is to highlight Australia for its attempts to create peace for Papuans and avoid conflict with Indonesia as for examples: 
(16) Mr. L'Estrange had offered no big concessions, but explained Australia's new hardline policies to deter future asylum seekers, sources confirmed (SMH).

As the secretary of the foreign affairs department officer, Mr. L'Estrange implicitly did not want to confess that granting a visa to Papuan asylum seekers broke the international law. This is an indication that Australia purposely wanted to interfere with the political conflict in Papua because it did not pay attention to the Indonesian government's protest towards this visa granting. This specific social actor, Mr. L'Estrange, mentioned assuring the newsreaders that the Australian Immigration Department did not refuse the Papuan asylum seekers but discourage other asylum seekers.

(17) Mr. Suebu attacked Dr. Yudhoyono's support for splitting Papua into two provinces, with an unresolved election for the governorship of the West Irian Jaya province last month (SMH).

The In group social actor, Mr. Suebu, was described above as an important man in Papua, who supported Papuans' struggle to reach their independence. He was the mouthpiece of Papuans and always protested the brutality of the Indonesian army during the military operation in Papua and Jakarta's domination toward Papua poverty.

The way this middle-class oriented newspaper in presenting the In group social actors in the above datum, which is using surname, indicated that this media wanted to show that these actors were reliable sources and witnesses for human rights abuses in Papua.

Different from the previous strategies in which the journalists mention the social actors in a specific way, the next data, show the strategy of genericization. It is a strategy of viewing social actors in a general way. The strategy has a purpose of creating a perception that the terrifying situation and intimidations were experienced by most of Papuans although this is one strategy to manipulate the newspaper's inability to provide valid information, for example;

(18) Now, hundreds of independence activists fear an intensified crackdown, amid police and military buildup (SMH).

These social actors were viewed through their collective terms that add an inclusive identity of this group and assimilates the group members into a community that shares similar values (Van Leuween, 2008). Therefore, SMH tried to emphasize the numbers of independence activists who always demanded the Indonesia government to stop the abuses. The use of this term showed that many activists were terrified of the terror done by the Indonesian military and police. In this case, the numbers of the actors were not mentioned accurately because this media implicitly wanted to express the big number of terrified people in Papua. Hence, the readers would be convinced that the conflict was a serious matter and needed to be world attention.

(19) Foreigners in Papua viewed suspiciously, especially non-government groups (SMH). 
(20) Ordinary Papuans, too, are deeply frustrated with their lack of economic progress (SMH).

The above data, Foreigners and Ordinary Papuans, show the next genericization strategy that SMH journalists used. Datum number 19 was identified in the news report about the issues of Papuan Independence. It was reported that some non-government groups were trying to provoke the Papuans to demand independence from Indonesia. In this part, SMH journalist was assumed not knowing for certain which and how many foreigners were the provocateurs. This strategy was used to shape the readers' opinion that Indonesia was not a safe place to visit by foreigners, and they had to be aware of that threat.

Datum number 20 indicates a similar meaning that all the ordinary Papuans felt that there would not be any improvement economically because of the rules implemented by the Indonesian Government. Not all the Papuans felt the same way, but the journalist used this strategy of genericization to blow up the failure of the Indonesian Government in improving the Papuans' poverty.

\section{Explanation}

SMH newspaper is published in Australia and written for Australian society. Thus, this newspaper production is constructed based on the social, cultural as well as the ideological context of Australian society, including how this newspaper viewed Papua conflict. The findings show that SMH valued Indonesia as the Out group negatively. This evaluation indicates that Australia has different ideologies from Indonesia; therefore, these differences were reflected in the way it looks at Papua conflict.

Firstly, a liberal party had controlled Australia quite strongly between 1996-2007. Under this control, Australia built some coalitions with some influential countries such as England and USA and other commonwealth countries to protect Australia's interest and security (Willoughby, 1960, p. 3) and provide international aid and assistance including helping refugees within the limits of its national resources (Hirst, 2002). It means that Australia has an underlying policy to assist asylum seekers from many countries, including Indonesia. This liberal-democratic country feels of having a responsibility to help the Papuans asylum seekers as they received hostile treatment from the Indonesian Government.

The SMH views the Indonesian elites and military, which is the representation of the Out group, are regarded as the actors responsible for the chaos in Papua during Papua conflict. This Australian media views these people negatively as they acted brutally and fiercely towards the indigenous Papuans who tried to free themselves from the control of the Indonesian Government. As a liberal-democratic country that respects human dignity, self-determination, 
and equality, Australia felt that what had been done by Indonesia was inhuman (Crosby, 2014, p.7). As Van Dijk (Nd, p.140) in Surjowati (2015, p.131) says that there are some relations between underlying ideologies in social cognition, mental models in personal cognition, and actual comprehension of production of text or talk under the influence of mental models of the situation. He furthermore says that ideologies unconsciously control the way of a social group thinks and beliefs, which finally become the fundamental social characteristics of a group (Van Dijk; 1995, p.47-142 in Asmaradhani, 2019). This means that what is printed in the news report is the reflection of the news workers' way of thinking, their behavior, and reaction towards a particular issue, such as an issue of Papua conflict. As opposed to Australia's foundations that are put forward freedom, tolerance, and an equal sense of fairness (Hirst, 2002), Australia through SMH then expresses its disappointment to the way Indonesia handled the conflict by giving negative evaluation towards the elites and military. The sources of political conflict in Papua is inequality of in every aspect of life such as economic, political, cultural and social aspect (May and Kegan, 1978, p.225) and Australia noticed these sources. Papua is a prosperous country, but social life is painful. Liberals believe that Papuans have freedom of choice because they have no hopes anymore to the government which must protect them from threat and strengthens them economically as the Federal Platform of Liberal Party of Australia (2002) says that prosperity and peace can only be obtained when people are given the opportunity and responsibility. They will feel real freedom when they are allowed to build their dream. When the ruler and the people respect each other, then the strength of uniting can be reached.

Secondly, the relationship established by Australia and its coalitions is based on the same interests and beliefs which they represent in their attitude and purposes and discourse. Australia's interference to the political conflict in Papua and its willingness to assist the Papuan asylum seekers illustrate its opposite policy with the Indonesian Government. It is an embodiment of its hidden political interests towards Papua. As neighboring countries, Australia and Indonesia are viewed as an odd couple because the relationship does not always run well. Often, there are tension, distrust, and suspicion (Burchill and Damien, 2001, p.67). Furthermore, Australia builds a strong coalition with the USA, which is suspiciously having hidden and big designs to Indonesia. The USA had been involved in Papua conflict since 1969 when the act of free choice was done. Papua has been a strategic target of the USA to conquer because Papua is well known for its wealth of natural resources such as gold, coal, and copper. Hence, Australia shows its support to the USA's design to Indonesia by exposing Indonesia's aggressive attack to indigenous Papuans. 


\section{CONCLUSION}

There are two different allotments of representing the social actors: the ones belong to the Out group (Indonesians), and the ones belong to the In group social actors (Australians and proindependence activists). Those representations serve two major divisions, depending on which groups are represented. Both the Out group and In group social actors were categorized in terms of assimilation, nomination and categorization, functionalization and identification, impersonalization, except for genericization and specification. However, these categorizations serve different purposes. The categorizations related to the Indonesian actors express a purpose to emphasize their negative attitude towards the conflict in Papua such as avoiding dialogue with the indigenous Papuans, intimidating Papuan villagers, torturing the Papuan activists, breaking a commitment to Papuan autonomy but emphasize positive attitudes of western social actors such as being peacemakers, facilitating Indonesian government and Papuans to negotiate, facilitating the Papuan asylum seekers by granting some visas for them and criticizing Indonesian military brutality towards Papuans. Those purposes are based on Australian ideology. Papua is viewed as Australia's different political ideologies. Australia is a liberal country in which freedom is essential. Every individual has their right to pursue their individual goals, and every individual within society has the right to get justice and protection from the government. Therefore, Australia has a responsibility to give aids to Papuans who are seeking a better place, as stated in international law. Furthermore, Australia's attitudes towards this conflict in Papua strengthened Indonesia's assumption that this country put special attention to political condition in Indonesia which is similar to his partner America with his hidden design for Indonesia

\section{REFERENCES}

Asmaradhani, A.I. (2019). Enemy construction in the declaration of war against Japanese empire: CDA perspective. Nobel Journal of Literature and Language Teaching .10 (2).117130. DOI: 10.15642/NOBEL.2019.10.10.2.117-130

Bell, A. (1991). The language of news media. London \& New York: Blackwell.

Bloor, M. \& Bloor, T. (2007). The practice of critical discourse analysis: An introduction. London: Hodder

Burchill, S. \& Kingsbury, D. (2001-12). Australia and Indonesia: Beyond stability towards order. Canberra Buletion of Public Administration.102. (67-73).

Caldas-Coulthard, C. R. (2003). Cross cultural representation of 'otherness' in media discourse in G Weiss and R. Wodak (eds). Critical discourse analysis: Theory \& interdisciplinary (pp.272-296). New York: Palgrave. 
Crosby, L. Modern Australia - The Challenge of Nation Building. (2002). The federal platform of the liberal party of Australia. Retrieved on 23 May, 2014 in www.liberal.org.au/info/docs/federalplatform.pdf.

Fairclough, N. (1989). Language and power: Discourse and power. London: Longman.

Fowler, R. (1991). Language in the news: Discourse and ideology in press. London \& New York: Routledge.

Fowler, R. (1996). "On critical linguistics." Caldas-Coulthard, CR \& Coulthard, M. (ed). Texts and practices: Readings in critical discourse analysis (p; 3-14). London: Routledge.

Ghannam, N. (2011). Newspaper ideology: A critical discourse analysis of an event published in six Lebanese newspapers [Thesis]. University of the Witwatersrand, South Africa.

Hirst, A. (2002). The federal platform of the liberal party of Australia. Retrieved on February 2020 in https://cdn.liberal.org.au/pdf/FederalPlatform.pdf

Kegan, P \& May, B. (1978). The Indonesian tragedy. London: Routledge.

Liao, N. (2012). Ideology in newspaper reporting: A cross cultural analysis of transitivity choices [Unpublished Thesis]. San Diego State University.

Naghty, E. C. (2010). Directing ideologies through media cartoons [Unpublished Thesis]. Universidad Computense de Madrid.

Rashidi, N. \& Rasti, A. (2012). Doing (in) justice to Iran's nuke activities? A critical discourse analysis of news reports of four western quality newspapers. American Journal of Linguistics, 1(10). 1-9

Richardson, J. E. (2007). Analysing newspapers: An approach from critical discourse analysis. New York: Palgrave Macmillan.

Surjowati, R. (2015) Newspaper ideology: Critical discourse analysis on 2002 Bali bombing and Papua conflict reported by Sydney Morning Herald. In: International Seminar "Language Maintenance and Shift" V ISSN; 2088-6799, 2-3 September 2015, Hotel NEO Semarang.

Van Dijk, T. A. (1998). Ideology: A multidisciplinary approach. London: Longman.

Van Dijk, T. A. (2000). Ideology and discourse: A multidisciplinary introduction. Retrieved on February, 20 , 2020.

In http://www.discourses.org/UnpublishedArticles/Ideology\%20and\%20discourse.pdf.

Van Dijk, T. A. (2006). Ideology and discourse analysis. Journal of Political Ideologies. 11(2), 115-140. Retrieved on February, 19, 2020. in https:// www.tanfondline.com/doi/abs/10.1080/13569310600687908

Van Dijk, T. A. (2009). Discourse studies: A multidisciplinary introduction. 2ed. London: Sage

Van Dijk, T. A. (2012). Discourse analysis as ideology analysis. Retrieved on March, 2012 in http://www.discourse.org/OldArticles/Discourse\%20\%20ideology\%20analys.pdf.

Van Leeuwen, T. (1996). The representation of social actors. In Caldas-Coulthard, C.R \& Coulthard, M. Eds. Texts and practices: Readings in critical discourse analysis. (pp 3270). London \& New York: Routledge.

Van Leeuwen, T. (2008). Discourse and practice: New tools for critical discourse analysis. New York: Oxford University Press. 
Vo, DD. (2011). Style, structure and ideology in English and Vietnamese business hard news reporting: A comparative study [Dissertation]. University of Adelaide.

Willoughby, J.R (1960). The official federal platform of the liberal party of Australia. Retrieved February, 22 , 2020 from https://parlinfo.aph.gov.au/parlInfo/download/library/partypol/1193431/upload_binary/11 93431.pdf;fileType $=$ application $\% 2 F p d f \#$ search $=\% 22$ library/partypol/1193431\%22

Wodak, R and Meyer, M. (2006). Methods of discourse analysis. London: Sage Publication. 